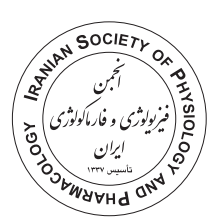

\title{
Comparison the cytotoxic effects of Ulva fasciata and Ulva lactuca on the MCF-7 and MDA-MB-231 breast cancer cell lines
}

Alireza Moulazadeh ${ }^{1}$, Razieh Ranjbar ${ }^{1}$, Maryam Hekmat ${ }^{2}$, Fatemeh Sedaghat ${ }^{3}$, Morteza Yousefzadi ${ }^{4}$, Sohrab Najafipour ${ }^{5,6 *}$ (D)

1. Noncommunicable Disease Research Center, Fasa University of Medical Sciences, Fasa, Iran

2. Student Research Committee, Fasa University of Medical Sciences, Fasa, Iran

3. Department of Marine Biology, Faculty of Marine Science and Technology, Hormozgan University, Bandar Abbas, Iran

4. Department of Biology, Faculty of Science, University of Qom, Qom, Iran

5. Medicinal Plant Research Center, Fasa University of Medical Sciences, Fasa, Iran

6. Department of Microbiology, Fasa University of Medical Sciences, Fasa, Iran

\begin{abstract}
Introduction: Marine seaweeds has received increased attention in the protection or treatment of cancer, because of their bioactive compounds. The aim of the present study was to evaluate the anticancer capacity of two green seaweeds, Ulva fasciata and Ulva lactuca.

Methods: The phenolic and flavonoid content of the hydro-methanolic extracts was measured, respectively by Folin-Ciocateu and aluminum chloride methods. The antioxidant activity of the extracts was evaluated by FRAP and DPPH assay and were compared to ascorbic acid. Cytotoxic effect of the extracts on the MCF-7 (ER ${ }^{+}$) and MDA-MB-231 (ER-) breast cancer cell lines was also evaluated by MTT assay after 48 and 72 hours of incubation.

Results: The phenolic and flavonoid content of Ulva fasciata was respectively $14.92 \pm 1.38$ $\mu \mathrm{gGAE} / \mathrm{mg}$ and $72.15 \pm 15.4 \mu \mathrm{gQE} / \mathrm{mg}$ which was significantly higher than Ulva lactuca. The reducing power and radical scavenging activity of Ulva fasciata was also higher. The cytotoxic effects of Ulva fasciata on the MCF-7 and MDA-MB-231 cell lines was more than Ulva lactuca, in concentration and time dependent manner. The cytotoxic effects of the both seaweeds were more potent on the MDA-MB-231 compared to the MCF-7 cell line and indicated an estrogen and progesterone receptor independent manner of cellular growth inhibition.

Conclusion: It is appeared that the Ulva fasciata extract was a better drug candidate in treatment of triple negative breast cancer due to higher antioxidant activity, phenolic and flavonoid content. Further studies in fractionation and bioactive extraction of Ulva fasciata are recommended.
\end{abstract}

Keywords:

Ulva fasciata

Ulva lactuca

Breast cancer

MTT assay

Antioxidant

\section{Introduction}

Cancer has become a serious crisis, which has led to the great mortality all over the world. Cancer is still one of the major obstacles of many countries despite of the vast improvement in the health care system. the number of new cancer cases is expected to rise by approximately $70 \%$ over the next 20 years, based on WHO evaluation (Arem and Loftfield, 2018). The latest statistic which

\footnotetext{
* Corresponding author: Sohrab Najafipour, Najafipour.s@fums.ac.ir

Received 10 August 2020; Revised from 8 December 2020; Accepted 8 February 2021
}

Citation: Moulazadeh A, Ranjbar R, Hekmat M, Sedaghat F, Yousefzadi M, Najafipour S. Comparison the cytotoxic effects of Ulva fasciata and Ulva lactuca on the MCF-7 and MDA-MB-231 breast cancer cell lines. Physiology and Pharmacology 2021; 25: 373-383. http://dx.doi.org/10.52547/phypha.25.4.2 
is published by American Cancer Society reveals that $1,762,450$ new cancer cases and 606,880 cancer deaths in 2019 are occurred in the United States (Siegel et al., 2019). Breast cancer is one of the most common malignancy, which accounts for about 14,000 deaths each year. Currently, the breast cancer therapy depends highly on the stage and tumor's subtypes. Surgical resection, chemotherapy, radiotherapy and hormone therapy are among the most common therapies, which are vastly being used. Although due to drug resistant, side effects and their high costs, new and more therapeutic drug should be developed (Waks and Winer, 2019).

Marine seaweeds are one of the traditional products which has recently received attention in the protection and treatment of cancer (Liu et al., 2012). Ulva fasciata and Ulva lactuca are among these traditional products and belong to Chlorophyceae family. These seaweeds contain rich resources of many minerals, amino acids and vitamins and produce a wide range of secondary antioxidant metabolites (Langeswaran et al., 2019; Lee et al., 2013). The aim of the present study was to evaluate the capacity of Ulva fasciata and Ulva lactuca in development of future new anti-cancer drugs. Therefore, the phenolic and flavonoid content of the Ulva fasciata and Ulva lactuca extracts was evaluated and their antioxidant activity and cytotoxic effects on the MCF-7 and MDA-MB-231 breast cancer cell lines was compared.

\section{Materials and methods}

\section{Collection and extraction of the seaweeds}

The seaweed samples were collected from the Persian Gulf in the coast of Bandar-Abbas, Hormozgan province, Iran. The collected seaweed species were identified by experts of Fasa Medicinal Plants Research Center (FMPRC) as Ulva fasciata and Ulva lactuca. The voucher numbers of FMPRC-100-5 and FMPRC-100-6 was assigned for the Ulva fasciata and Ulva lactuca respectively in the herbarium of FMPRC, Fasa University of Medical Sciences, Iran. This study was approved by Medical Ethics Committee of Fasa University of Medical Sciences (Code: IR.FUMS.REC.1396.314).

Extraction was done by hydro-methanolic maceration method. The powders of Ulva fasciata and Ulva lactuca $(100 \mathrm{~g})$ was immersed in methanol (70:30 v/v) and kept at room temperature and darkness for one week with continuous stirring. The solid and insoluble particles were removed by centrifugation $(500 \mathrm{~g})$ and filtration (wattman filter 14). The excess solvent was evaporated at $55^{\circ} \mathrm{C}$ and the concentrated extract was incubated at $45^{\circ} \mathrm{C}$ for $24 \mathrm{~h}$ to dry (Hoseinzadeh and Shirazinejad, 2019; Meshkibaf et al., 2010). Dried extracts (500 mg) was dissolved in $5 \mathrm{~mL}$ of dimethylsulfoxide (DMSO) (Merck, Germany) to prepare a $100 \mathrm{mg} / \mathrm{mL}$ stock solution of the extracts. The solution was sterilized with a $0.22 \mu \mathrm{m}$ filter and diluted $1: 100(\mathrm{v} / \mathrm{v})$ to prepare the working solution of $1 \mathrm{mg} / \mathrm{mL}$ with distilled water and complete Dulbecco's modified Eagle medium (DMEM, containing $10 \%$ fetal bovine serum) for biochemical and cell culture experiments respectively.

\section{Measurement of phenolic content of the extracts}

The phenolic content of the Ulva fasciata and Ulva lactuca extracts was measured using the Folin- Ciocateu method. Accordingly, $500 \mu \mathrm{L}$ of the Folin-Ciocateu reagent $(10 \% \mathrm{v} / \mathrm{v})$ was added to the $100 \mu \mathrm{L}$ of the each extract $(1 \mathrm{mg} / \mathrm{ml})$ and incubated for $5 \mathrm{~min}$ at room temperature and darkness. Then $400 \mu \mathrm{L}$ of sodium carbonate $(7.5 \% \mathrm{w} / \mathrm{v})$ was added to the sample and was kept at room temperature and darkness for $60 \mathrm{~min}$. Finally, absorbance of the samples was measured at $765 \mathrm{~nm}$ by Synergy HTX multi-mode reader. Gallic acid was also used as standard and the phenol content of the extracts was reported in microgram gallic acid equivalent (GAE) per milligram of dry weight ( $\mu \mathrm{g} \mathrm{GAE} / \mathrm{mg}$ ) (Hoseini et al., 2019). All measurements were done in duplicate.

\section{Measurement of flavonoid content of the extracts}

Aluminum chloride method was used to measure the flavonoid content of the extracts. Accordingly, $50 \mu \mathrm{L}$ of the aluminum chloride $(10 \% \mathrm{w} / \mathrm{v})$ and $50 \mu \mathrm{L}$ of the sodium nitrite $(10 \% \mathrm{w} / \mathrm{v})$ were added to $200 \mu \mathrm{L}$ of the each extract $(1 \mathrm{mg} / \mathrm{mL})$. The solution was incubated $5 \mathrm{~min}$ at room temperature and darkness, then $700 \mu \mathrm{L}$ of sodium hydroxide $(4 \% \mathrm{w} / \mathrm{v})$ was added and the total volume of the solution was $1 \mathrm{~mL}$. After complete stirring, the solution was again incubated at room temperature and darkness for $15 \mathrm{~min}$ and the sample absorbance was read at $510 \mathrm{~nm}$ using a Synergy HTX multi-mode reader. Quercetin was also used as standard and the flavonoid content of the extracts was reported in microgram quercetin equivalent $(\mathrm{QE})$ per milligram of dry weight ( $\mu \mathrm{g} \mathrm{QE} /$ $\mathrm{mg}$ ) (Moulazadeh et al., 2021). All measurements were done in duplicate. 


\section{Evaluation of antioxidant activity}

In the present study, ferric reducing antioxidant power (FRAP) and 2,2-diphenyl-1-picryl-hydrazyl (DPPH) methods were used to compare the antioxidant activity of the Ulva fasciata and Ulva lactuca extracts. The FRAP assay was used to investigate the potency of monovalent antioxidants that capable of reducing $\mathrm{Fe}^{3+}$ to $\mathrm{Fe}^{2+}$ ions. Whereas in the DPPH method, the total radical scavenging activity is determined with reducing the stable nitrogen radical (DPPH radical) (Valverde Malaver et al., 2015).

\section{Evaluation of the monovalent reducing power}

As mentioned, the FRAP assay measures the antioxidant capacity of the extracts by reducing the $\mathrm{Fe}^{3+}$ ions (present in the Fe-TPTZ complex) to $\mathrm{Fe}^{2+}$ ions, so it's called monovalent reduction (Gallego et al., 2013). According to the previous study (Wang et al., 2016), $50 \mu \mathrm{L}$ of the seaweed extracts $(1 \mathrm{mg} / \mathrm{mL})$ were added to the FRAP working solution $(1.5 \mathrm{~mL})$ and mixed. The absorbance of the colored solution was read at $593 \mathrm{~nm}$ after $10 \mathrm{~min}$ of incubation at $37^{\circ} \mathrm{C}$. Serial dilution of $\mathrm{FeSO}_{4}$ solution $(1 \mathrm{mM})$ was used as standard and the antioxidant activity of the extract was reported in $\mu \mathrm{molFe}^{2+} / \mathrm{g}$. All measurements were done in duplicate.

\section{Determination of total radical scavenging activity}

Total radical scavenging activity of the extracts is determined by DPPH assay. The DPPH radicals has a purple color that turns to yellow after reduction by antioxidants in the herbal extracts. The intensity of colorlessness indicates the antioxidant activity of the extracts. Accordingly, serial dilution of the extracts (100, 200,500 and $1000 \mu \mathrm{g} / \mathrm{mL}$ ) was prepared using ethanol $70 \%$. The prepared extracts $(40 \mu \mathrm{L})$ was added to 160 $\mu \mathrm{L}$ of the DPPH radicals $(0.3 \mathrm{mM})$ and kept at room temperature and darkness for $30 \mathrm{~min}$. Finally, the optical absorption changes of the samples were determined at $517 \mathrm{~nm}$ using Synergy HTX multi-mode reader. All measurements were done in duplicate. Ascorbic acid, a potent antioxidant, was used as a basis for comparing the results (Wang et al., 2016). The antioxidant activity was calculated as the percentage of the free radicals reduction relative to the control group using the following equation:

Antioxidant activity $=[$ (optical absorption of the control group- optical absorption of the experimental group)/ optical absorption of the control group $] \times 100$

\section{Cell culture}

Two invasive breast ductal carcinoma cell lines, the human MDAMB231 (estrogen receptor negative [ER-] with aggressive phenotype) and MCF7 (ER+, less aggressive) cell lines were purchased from the National Cell Bank of Pasteur Institute of Iran. Cells were cultured in DMEM (Gibco, USA) with 10\% fetal bovine serum (Gibco, USA) and 1\% penicillinstreptomycin (Bio idea, Iran) at $37^{\circ} \mathrm{C}$ in a humidified $5 \% \mathrm{CO}_{2}$ incubator. Cells with confluency of $70 \%$ were used for subsequent experiments (Galavi et al., 2016).

\section{Morphology alteration and cytotoxic effects}

Cell viability and cytotoxic effect of the extracts were carried out through the MTT assay as described previously (Galavi et al., 2016). The MDA-MB-231 and MCF-7 cell lines with a density of 10,000 cells per well $(150 \mu \mathrm{L})$ were seeded in the 96-well plates and int cubated overnight to reach the confluency of $70 \%$ approximately. The confluent cells were treated with the concentrations of 500, 750 and $1000 \mu \mathrm{g} / \mathrm{mL}$ of Ulva fasciata and Ulva lactuca, and incubated for 48 and 72 hours. The untreated wells were assigned as the negative control. The morphology alteration of different groups was evaluated by the invert microscope at the end of incubation time.

For MTT assay, the culture medium was changed with fresh media and $20 \mu \mathrm{L}$ of the MTT solution $(0.5 \mathrm{mg} /$ $\mathrm{mL})$ was added to the each well $(1: 10 \mathrm{v} / \mathrm{v})$ and incubated for $4 \mathrm{~h}$ in $\mathrm{CO}_{2}$ incubator. Next, the supernatant was removed carefully and $200 \mu \mathrm{L}$ of DMSO was added to the each well for solubilization of the formazan crystals. Plates were shacked for $15 \mathrm{~min}$ and read at $540 \mathrm{~nm}$ using the Synergy HTX multi-mode reader. The results were reported as cell viability percentage that calculated by dividing the percentage of absorbance in the treated cells (test) by the absorbance of untreated (control) cells: $[\%$ viability $=($ test $/$ control $) \times 100 \%]$. The cytotoxic effects of the extracts also calculated as reduction rate in the cell viability. Finally, the minimum concentration of the extracts that giving at least $50 \%$ of the cancer cell viability was calculated as IC50 value with linear regression (Galavi et al., 2016 ; Moulazadeh et al., 2020).

\section{Statistical analysis}

Data are expressed as the mean $\pm \mathrm{SD}$ and compared between the experimental groups by t-test and one-way 

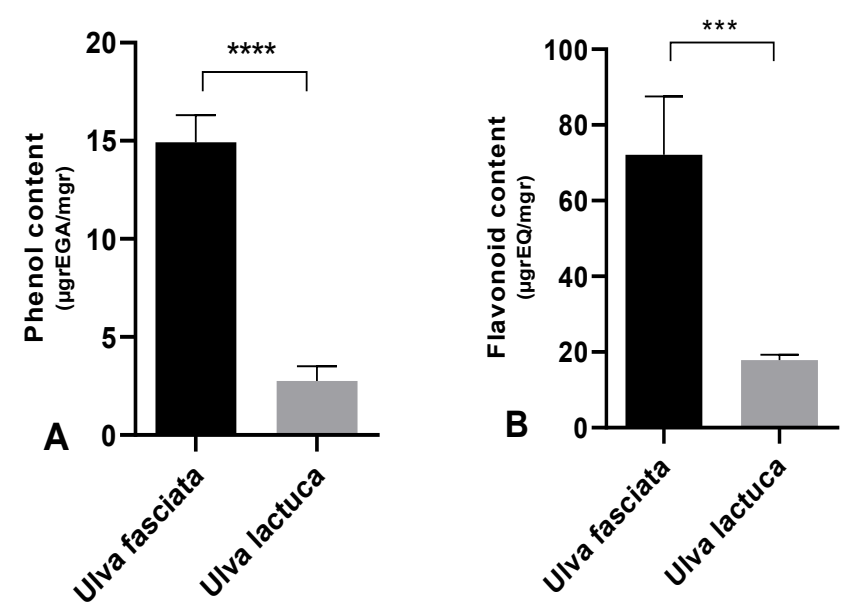

FIGURE 1. Phenolic (A) and flavonoid (B) content of Ulva fasciata and Ulva lactuca. Data are expressed as mean \pm SD. Statistical difference between the groups was investigated by t-test and $P$-value $<0.05$ was considered significant. The bullet of $\left(^{* * *}\right)$ means $P<0.001$ and the bullet of $\left(^{* * * *}\right)$ means $P<0.0001$.

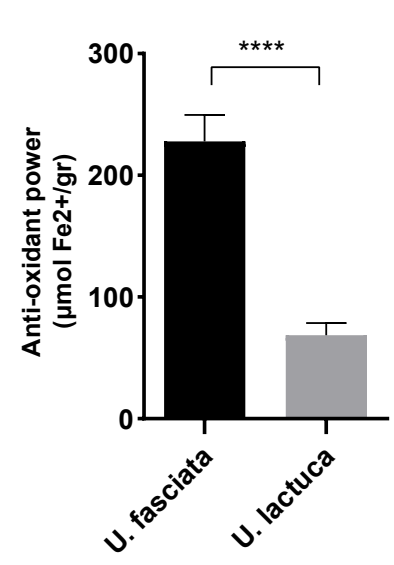

FIGURE 2. Monovalent reducing power of the Ulva fasciata and Ulva lactuca extract. Data are expressed as mean \pm SD. Statistical difference between the groups was investigated by t-test and $P$-value $<0.05$ was considered significant. The bullet of $\left({ }^{* * * *}\right)$ means $P<0.0001$.

TABLE 1: Total phenolic and flavonoid content and antioxidant activity of Ulva fasciata and Ulva lactuca. Data are shown as mean \pm SD. Statistical difference between the groups was investigated by t-test and $P$-value $<0.05$ was considered as significant.

\begin{tabular}{ccccc} 
& $\begin{array}{c}\text { Phenol content } \\
(\mu \mathrm{g} \mathrm{GAE} / \mathrm{mg})\end{array}$ & $\begin{array}{c}\text { Flavonoid content } \\
(\mu \mathrm{g} \text { QE/mg })\end{array}$ & \multicolumn{2}{c}{ Antioxidant activity } \\
\cline { 4 - 5 } & $14.92 \pm 1.38$ & $72.15 \pm 15.4$ & $\begin{array}{c}\text { FRAP assay } \\
(\mu \mathrm{molFe} / \mathrm{g})\end{array}$ & $\begin{array}{c}\text { DPPH IC50 } \\
(\mu \mathrm{g} / \mathrm{mL})\end{array}$ \\
Ulva fasciata & $2.75 \pm 0.74$ & $1.43 \pm 17.88$ & $68.69 \pm 9.98$ & $>1000$ \\
Ulva lactuca & $<\mathbf{0 . 0 0 0 1}$ & $\mathbf{0 . 0 0 0 4}$ & $<\mathbf{0 . 0 0 0 1}$ & - \\
\hline $\boldsymbol{P}$-value & & &
\end{tabular}

analysis of variance (ANOVA). Significant difference was determined at the level of $P<0.05$. The IC50 value was calculated by linear and four parametric logistic regressions, respectively for MTT assay and total radical scavenging activity (DPPH assay). All analyses were performed using GraphPad Prism 8.0.2 (Chen et al., 2013).

\section{Results}

\section{Phenolic and flavonoid content of the extracts}

The phenolic content of the extracts was calculated by Folin-Ciocateu method based on the standard line equation of gallic acid $\left(y=278.59 x-48.578, R^{2}=0.9902\right)$. As it is shown in the Table 1, the phenolic content of the Ulva fasciata extract was $14.92 \pm 1.38 \mu \mathrm{g} \mathrm{GAE} / \mathrm{mg}$, which was significantly $(P<0.0001)$ higher than the phenolic content of Ulva lactuca $(2.75 \pm 0.74 \mu \mathrm{g} \mathrm{GAE} /$ $\mathrm{mg}$ ). The flavonoid content of the extracts was also calculated by the aluminum chloride method based on the standard line equation of quercetin $(y=278.59 x-48.578$, $\mathrm{R}^{2}=0.9968$ ). Accordingly, the flavonoid content of the
Ulva fasciata extract was $72.15 \pm 15.4 \mu \mathrm{g} \mathrm{QE} / \mathrm{mg}$ which was significantly $(P=0.0004)$ higher than the flavonoid content of Ulva lactuca (17.88 $\pm 1.43 \mu \mathrm{g}$ QE/mg).

\section{Monovalent reducing power}

The monovalent reducing power of the extracts was calculated by the FRAP assay based on the FeSO4 standard line equation $\left(\mathrm{y}=1642.1 \mathrm{x}-272.29, \mathrm{R}^{2}=0.9982\right)$. According to the Table 1 and Figure 2, the antioxidant activity of the Ulva fasciata extract was $228 \pm 21.73 \mu \mathrm{mol}$ $\mathrm{Fe}^{2+} / \mathrm{g}$ which was significantly $(P<0.0001)$ higher than Ulva lactuca $\left(68.69 \pm 9.98 \mu \mathrm{mol} \mathrm{Fe}{ }^{2+} / \mathrm{g}\right)$.

\section{Total radical scavenging activity}

The total radical scavenging activity of the extracts was determined by DPPH assay. The highest radical scavenging activity of the extracts was related to ascorbic acid $(\mathrm{IC} 50=30.99 \mu \mathrm{g} / \mathrm{mL})$, the Ulva fasciata (IC50>1000 $\mu \mathrm{g} / \mathrm{mL}$ ) and Ulva lactuca extracts (IC50>1000 $\mu \mathrm{g} / \mathrm{mL}$ ), respectively. According to the Table 2, the antioxidant activity of Ulva fasciata was 
TABLE 2: Total radical scavenging activity (\%) of the Ulva fasciata and Ulva lactuca extracts and ascorbic acid in the different concentrations. Data are expressed as mean \pm SD. The $P$-value column indicate statistical differences between Ulva fasciata and Ulva lactuca by t-test analysis. The $P$-value $<0.05$ was considered as significant.

\begin{tabular}{|c|c|c|c|c|c|c|c|}
\hline \multirow{2}{*}{$\begin{array}{l}\text { CONC } \\
(\mu \mathrm{g} / \mathrm{mL})\end{array}$} & \multicolumn{2}{|c|}{ Ulva fasciata } & \multicolumn{2}{|c|}{ Ulva lactuca } & \multirow{2}{*}{$P$-value } & \multicolumn{2}{|c|}{ Ascorbic Acid } \\
\hline & Mean \pm SD & IC50 & Mean \pm SD & IC50 & & Mean \pm SD & IC50 \\
\hline 100 & $8.88 \pm 2.42$ & \multirow{4}{*}{$>1000$} & $4 \pm 2.54$ & \multirow{4}{*}{$>1000$} & 0.049 & $84.10 \pm 4.68$ & \multirow{4}{*}{30.99} \\
\hline 200 & $11.32 \pm 2.20$ & & $4.78 \pm 2.59$ & & 0.017 & $92.42 \pm 0.03$ & \\
\hline 500 & $14.18 \pm 1.94$ & & $5.70 \pm 2.07$ & & 0.002 & $92.62 \pm 0.05$ & \\
\hline 1000 & $18.75 \pm 1.51$ & & $17.80 \pm 3.03$ & & 0.653 & $93.09 \pm 0.40$ & \\
\hline
\end{tabular}

TABLE 3: The viability of the MCF-7 and MDA-MB 231 breast cancer cell lines after treatment (48 and 72 hours) with the Ulva fasciata and Ulva lactuca extract. Data were expressed as mean $\pm \mathrm{SD}$ and analyzed by t-test. The $P$-value $<0.05$ was considered as significant.

\begin{tabular}{|c|c|c|c|c|c|c|c|c|c|}
\hline \multirow{3}{*}{$\begin{array}{l}\text { Cell } \\
\text { line }\end{array}$} & \multirow{3}{*}{ Time } & \multirow{3}{*}{$\begin{array}{c}\text { CONC } \\
(\mu \mathrm{g} / \mathrm{mL})\end{array}$} & \multicolumn{3}{|c|}{ Ulva fasciata } & \multicolumn{3}{|c|}{ Ulva lactuca } & \multirow{3}{*}{$P$-value } \\
\hline & & & \multicolumn{2}{|c|}{ Viability \% } & \multirow{2}{*}{ IC50 } & \multicolumn{2}{|c|}{ Viability \% } & \multirow{2}{*}{ IC50 } & \\
\hline & & & Mean & STD & & Mean & STD & & \\
\hline \multirow{6}{*}{ 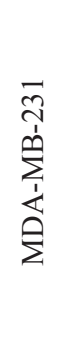 } & \multirow{3}{*}{$48 \mathrm{~h}$} & 500 & 85.71 & 1.69 & \multirow{3}{*}{$>1000$} & 89.21 & 2.23 & \multirow{3}{*}{$>1000$} & 0.09 \\
\hline & & 750 & 70.09 & 7.85 & & 76.89 & 5.52 & & 0.28 \\
\hline & & 1000 & 55.98 & 4.05 & & 65.05 & 2.02 & & 0.02 \\
\hline & \multirow{3}{*}{$72 \mathrm{~h}$} & 500 & 72.54 & 9.01 & \multirow{3}{*}{804.1} & 79.75 & 4.19 & \multirow{3}{*}{848.6} & 0.27 \\
\hline & & 750 & 51.52 & 3.78 & & 55.99 & 1.22 & & 0.18 \\
\hline & & 1000 & 27.33 & 3.81 & & 31.75 & 0.82 & & 0.12 \\
\hline \multirow{6}{*}{$\begin{array}{l}\hat{1} \\
\stackrel{1}{\Sigma}\end{array}$} & \multirow{3}{*}{$48 \mathrm{~h}$} & 500 & 98.56 & 5.17 & \multirow{3}{*}{$>1000$} & 103.04 & 5.91 & \multirow{3}{*}{$>1000$} & 0.21 \\
\hline & & 750 & 98.53 & 11.25 & & 96.20 & 11.15 & & 0.81 \\
\hline & & 1000 & 77.74 & 5.33 & & 96.06 & 4.97 & & 0.003 \\
\hline & \multirow{3}{*}{$72 \mathrm{~h}$} & 500 & 99.58 & 1.78 & \multirow{3}{*}{$>1000$} & 100 & 5.32 & \multirow{3}{*}{$>1000$} & 0.90 \\
\hline & & 750 & 78.27 & 6.97 & & 98.79 & 3.38 & & 0.01 \\
\hline & & 1000 & 68.72 & 1.44 & & 97.75 & 1.23 & & 0.0002 \\
\hline
\end{tabular}

significantly higher than the Ulva lactuca extract on the concentrations of 100,200 and $500 \mu \mathrm{g} / \mathrm{mL}$. However, at concentration of $1000 \mu \mathrm{g} / \mathrm{mL}$, there was no significant difference between the extracts (Table 2). There was a direct relationship between the concentration of the extracts and their antioxidant activity. The antioxidant activity of the Ulva fasciata and Ulva lactuca extracts in concentration of $1000 \mu \mathrm{g} / \mathrm{mL}$ compared to $100 \mu \mathrm{g} / \mathrm{mL}$ increased by 1.11 and 3.45 fold, respectively.

\section{Analysis of cell morphology}

The morphology of the MDA-MB-231 cells changed in a concentration and time dependent manner in treatment with the Ulva fasciata and Ulva lactuca extracts. According to the Figure 4, the MDA-MB-231 cells treated with Ulva fasciata were ruptured. The cell debris, granulated cellular contents, dropsy and shrinkage were increased clearly. Whereas, the MDA-MB-231 cells after treatment with Ulva lactuca were narrowed and slightly granulated. This cellular morphology intensified with concentration and time increasing, and the highest rate of cell granulation, shrinkage and cell rupture was seen after $72 \mathrm{~h}$ of treatment with the concentration of $1000 \mu \mathrm{g} / \mathrm{mL}$ Ulva lactuca extract (Figure 4). The MCF-7 cell line also showed morphological changes in treatment with the Ulva fasciata extract. These morphological changes were concentration and time dependent with shrinkage and disruption of cell integrity. Nevertheless, the Ulva lactuca extract did not show any specific morphological changes on the MCF-7 cell line 


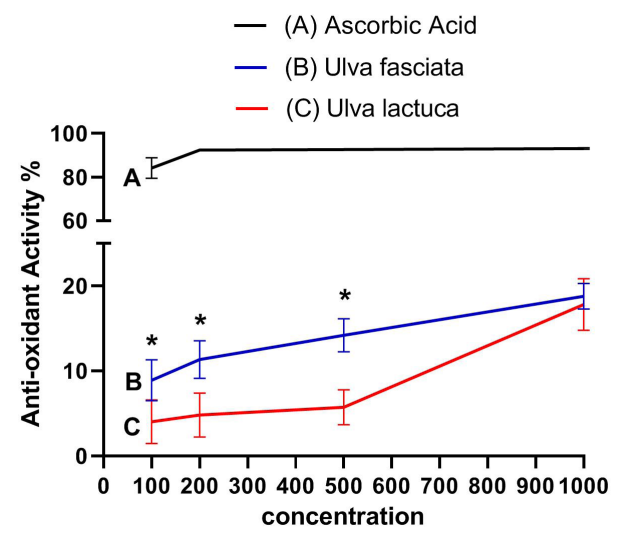

FIGURE 3. Total radical scavenging activity of the Ulva fasciata and Ulva lactuca extract and ascorbic Acid. Data are expressed as mean \pm SD and analyzed by t-test. The $P$-value $<0.05$ was also considered as significant. The bullet ( $\left.{ }^{*}\right)$ Indicates a statistically significant difference between Lawsonia inermis and Haplophyllum vermiculare as $P$-value $<0.05$ by t-test.

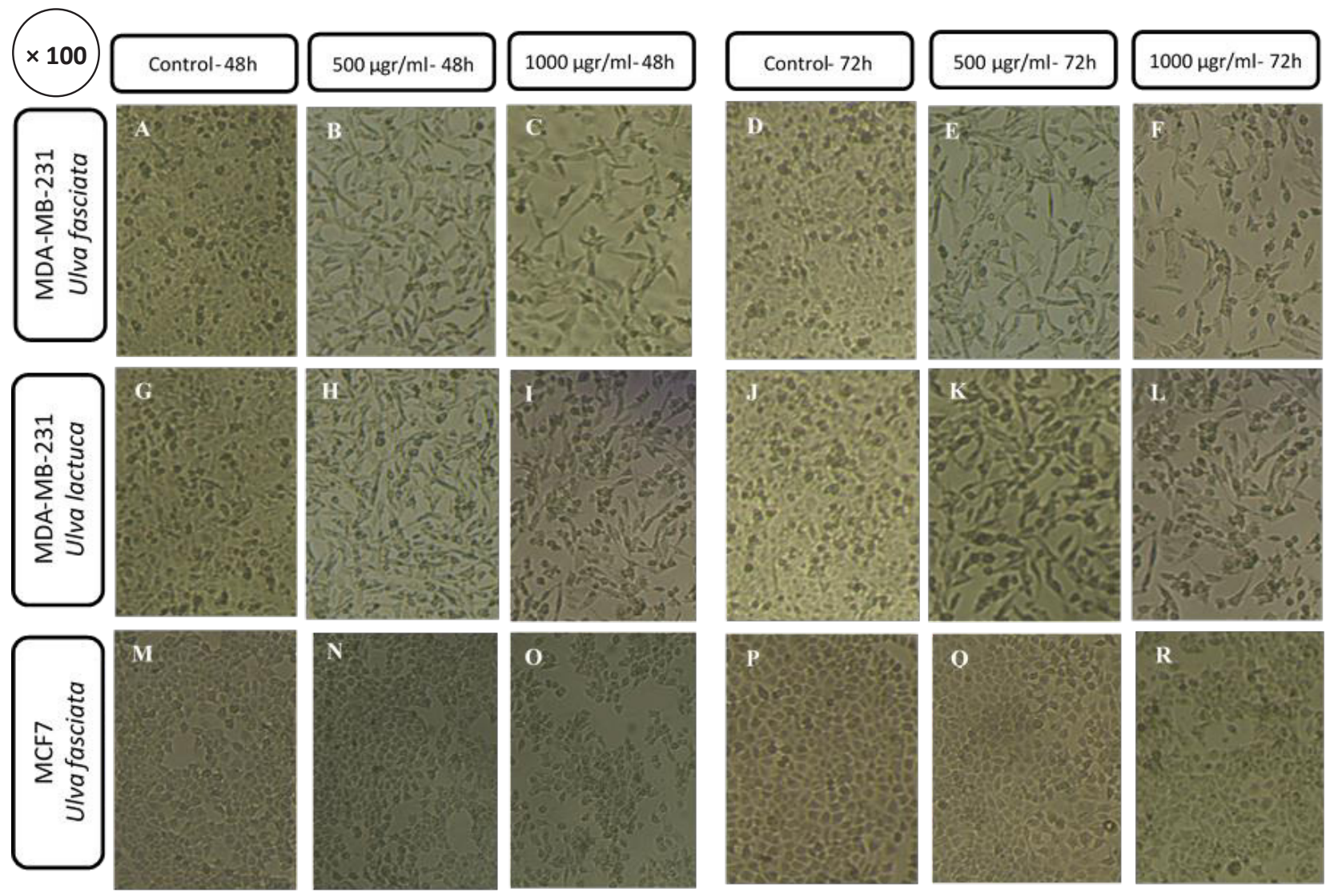

FIGURE 4. The images $(\times 100)$ of morphological alterations of the MDA-MB-231 (A-L) and MCF-7 (M-R) cell lines in treatment with 500 and $1000 \mu \mathrm{g} / \mathrm{ml}$ concentrations of Ulva fasciata (A-F, M-R) and Ulva lactuca (G-L) extract after 48 and 72 hours of incubation. For brevity, the image of the MCF-7 and MDA-MB-231 cell lines treated with the concentration of $750 \mu \mathrm{g} / \mathrm{ml}$ of the extracts is not shown. Also, the image of MCF-7 treated with Ulva lactuca is not demonstrated due to no morphological changes.

(Images not reported).

\section{Cytotoxic effects}

According to the Figure 5, treatment of the MDAMB-231 cell line with the Ulva fasciata extract resulted to a significant reduction of the cell viability by $14.29 \%$ $(P=0.01), 29.91 \%(P=0.0001)$ and $44.02 \%(P<0.0001)$ after $48 \mathrm{~h}$ of incubation, respectively on the concentrations of 500,750 and $1000 \mu \mathrm{g} / \mathrm{mL}$. The viability of the MDA-MB-231 cell line after $72 \mathrm{~h}$ of incubation with the Ulva fasciata extract also decreased by $27.46 \%$ $(P=0.009), 48.48 \%(P<0.0001)$ and $72.67 \%(P<0.0001)$ on the concentrations of 500,750 and $1000 \mu \mathrm{g} / \mathrm{mL}$ respectively, which was statistically significant. Treatment 


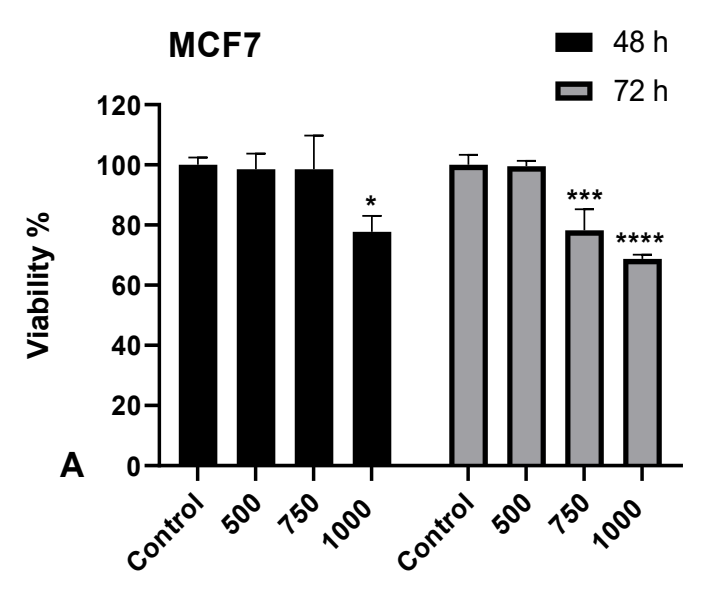

Ulva fasciata CONC

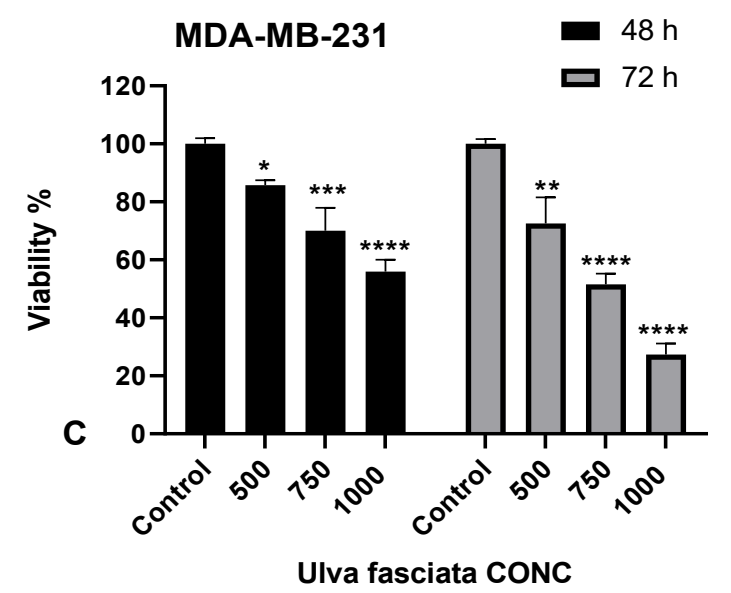

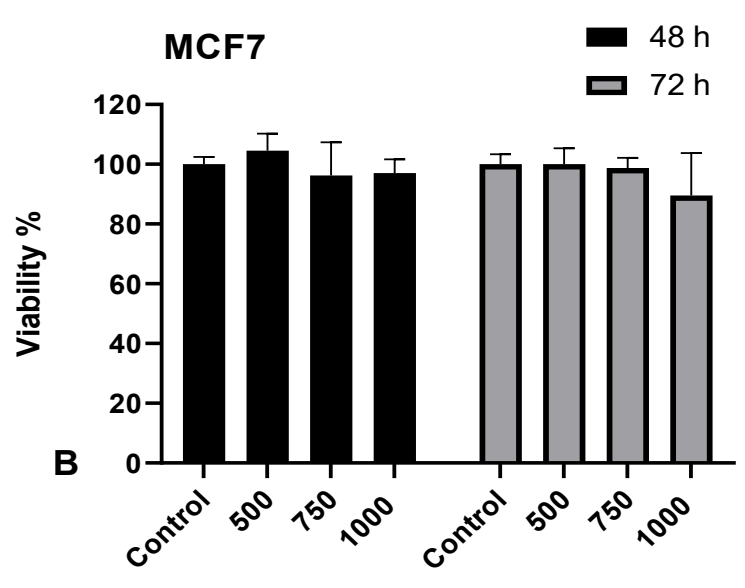

Ulva lactuca CONC

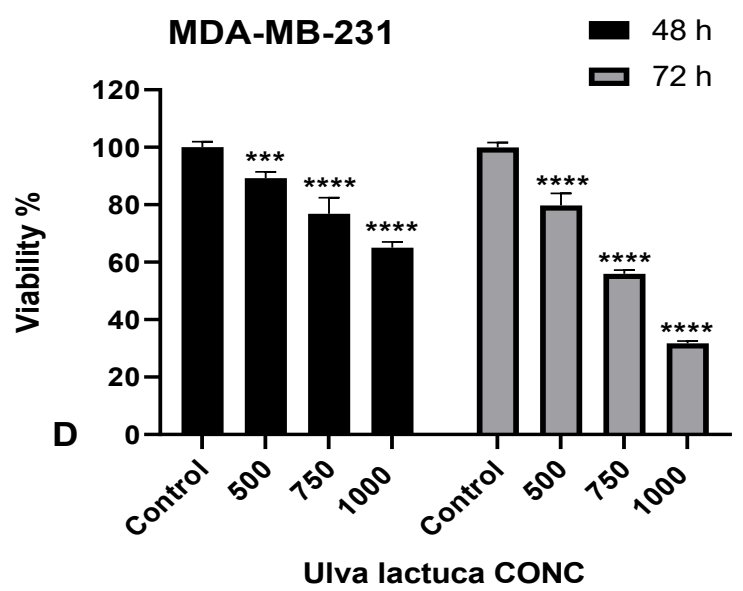

FIGURE 5. The viability of the MCF-7 and MDA-MB 231 breast cancer cell lines after treatment (48 and 72 hours) with the Ulva fasciata and Ulva lactuca extract on the concentrations of 500, 750 and $1000 \mu \mathrm{g} / \mathrm{ml} .{ }^{*} P<0.05,{ }^{* *} P<0.01,{ }^{* * *} P<0.001$ and ${ }^{* * * *} P<0.0001$

of the MDA-MB-231 cell line with Ulva lactuca also resulted in a significant reduction of $10.79 \%(P=0.0006)$, 23.11\% $(P<0.0001)$ and $34.95 \%(P<0.0001)$ in cell viability $48 \mathrm{~h}$ of incubation, respectively on the concentrations of 500,750 and $1000 \mu \mathrm{g} / \mathrm{mL}$ after. The vi $\theta$ ability of the MDA-MB-231 cell line after $72 \mathrm{~h}$ of incubation with the Ulva lactuca extract also decreased by $20.25 \%(P<0.0001), 44.01 \%(P<0.0001)$ and $68.25 \%$ $(P<0.0001)$ in the concentrations of 500, 750 and 1000 $\mu \mathrm{g} / \mathrm{mL}$ respectively, which was statistically significant. According to the Table 3, the cytotoxic effects of Ulva fasciata was significantly higher than Ulva lactuca in the concentrations of $1000 \mu \mathrm{g} / \mathrm{mL}(P=0.02)$ after $48 \mathrm{~h}$ of incubation. The IC50 value of the Ulva fasciata and Ulva lactuca extracts after $48 \mathrm{~h}$ of incubation on the MDAMB-231 was more than $1000 \mu \mathrm{g} / \mathrm{mL}$ and after $72 \mathrm{~h}$ of incubation was 804.1 and $848.6 \mu \mathrm{g} / \mathrm{mL}$ respectively.

Treatment of the MCF-7 cell line with the Ulva fascia- ta extract $(1000 \mu \mathrm{g} / \mathrm{mL})$ reduced the viability of the cells by $22.26 \%$ after $48 \mathrm{~h}$ of incubation, which was statistically significant $(P=0.01)$. After $72 \mathrm{~h}$ of incubation, the Ulva fasciata extract reduced the viability of the MCF-7 cell line by $21.73 \%(P=0.0005)$ and $31.28 \%(P<0.0001)$ in the concentrations of 750 and $1000 \mu \mathrm{g} / \mathrm{mL}$, respectively. However, treatment of the Ulva lactuca extract with the MCF-7 cell line did not lead to a significant reduction in cell viability. According to the Table 3, the IC50 value of the Ulva fasciata and Ulva lactuca extracts after 48 and 72 hours of incubation was more than $1000 \mu \mathrm{g} / \mathrm{mL}$. The cytotoxic effects of the Ulva fasciata and Ulva lactuca extracts $(1000 \mu \mathrm{g} / \mathrm{mL})$ had a statistically significant difference $(P=0.003)$ after $48 \mathrm{~h}$ of incubation. After $72 \mathrm{~h}$ of incubation, the cytotoxic effects of Ulva fasciata was also significantly higher than the Ulva lactuca extract in the concentrations of $750 \mu \mathrm{g} / \mathrm{mL}$ $(P=0.01)$ and $1000 \mu \mathrm{g} / \mathrm{mL}(P=0.0002)$. 


\section{Discussion}

Seaweeds have achieved a special place in traditional medicine research. They have active ingredients which have made them effective in the treatment of non-communicable diseases (El Gamal, 2010; Moulazadeh et al., 2021). Seaweed has shown great potential in the production of new drugs especially in cancer, and has been called "the sea, the future pharmacy" (Mohebbi et al., 2014). In the present study, the capacity of Ulva fasciata and Ulva lactuca seaweeds was evaluated in the production of future new anticancer drugs. The present study demonstrated the cytotoxic effect of Ulva fasciata and Ulva lactuca hydro-methanolic extract in a time and dose dependent manner. However, the Ulva fasciata extract had a stronger cytotoxic effect than Ulva lactuca extract on the MCF-7 and MDA-MB-231 breast cancer cell lines.

This stronger cytotoxic effects of Ulva fasciata was probably due to the potent antioxidant activity and more rich phenolic and flavonoid content of Ulva fasciata (Langeswaran et al., 2019; Nordin et al., 2018). Polyphenols have potent antioxidant activity and are able to modulate molecular targets and signaling pathways in cell survival, proliferation, migration and angiogenesis. As the best of our knowledge, the antioxidant activity of Ulva lactuca was not evaluated so far, and limited study evaluated the antioxidant activity of Ulva fasciata (Nordin et al., 2018). Langeswaran et al. (2019) was reported the high DPPH radical scavenging activity of Ulva fasciata. They also reported that the methanolic extract of Ulva fasciata has the ability to trap nitric oxide and superoxide radicals and has the protective effect on DNA sugar damage. In the present study, the higher antioxidant activity of the Ulva fasciata extract was double confirmed by DPPH and FRAP assay, and indicated that Ulva fasciata contains higher radical scavenging activity and reducing power. So Ulva fasciata with high phenolic and flavonoid content and higher antioxidant activity probably is effective in cancer prevention and treatment (Zhou et al., 2016).

As mentioned, the IC50 value of the Ulva fasciata and Ulva lactuca extracts on the MDA-MB-231 cell line after $72 \mathrm{~h}$ of incubation was 804.1 and $848.6 \mu \mathrm{g} /$ $\mathrm{mL}$, respectively. The IC50 value of these extracts in treatment to the MCF-7 (48 and 72 hours of incubation) and MDA-MB-231 (48h of incubation) cell lines was more than $1000 \mu \mathrm{g} / \mathrm{mL}$. The cytotoxic effect of the plant extracts and traditional medicine products are divided into four categories according to the concentration of IC50. In this category, plants with the IC50 values of 0-20 $\mu \mathrm{g} / \mathrm{mL}, 20-100 \mu \mathrm{g} / \mathrm{mL}, 100-1000 \mu \mathrm{g} / \mathrm{mL}$ and more than $1000 \mu \mathrm{g} / \mathrm{mL}$ respectively are considered as very active, moderately active, weakly active and finally inactive drugs (Atjanasuppat et al., 2009; Baharum et al., 2014). Therefore, the Ulva fasciata and Ulva lactuca total extracts are assigned as weakly active compounds on the MDA-MB-231 (in 72h of incubation) and inactive drugs on the MCF-7 cell lines. Similar studies on other cell line categories have shown similar results. For example, a study by Guedes et al. (2013) showed that the various extracts of Ulva lactuca did not have cytotoxic effect on the NCI-H292, HEp-2 and K562 cell lines.

So far limited studies have evaluated the cytotoxic effects of Chlorophyceae family total extracts on the breast cancer cell lines. Most of the previous study indicated relatively weak cytotoxic effects of the Ulva fasciata and Ulva lactuca extracts. For example, Mosaddegh et al. (2014) showed that the Persian Gulf native Ulva fasciata had little cytotoxic effect on the MCF-7 cell line after $72 \mathrm{~h}$ of treatment and was in the range of inactive compounds. Arsianti et al. (2016) showed that the ethanolic extract of Ulva lactuca with the IC50 value of $246.8 \mu \mathrm{g} / \mathrm{mL}$ is weakly active on the MCF-7 cell line. It was also shown in the study of Mashjoor et al. (2016) that the methanolic extract of Ulva flexuosa with the IC50 value of $107.48 \mu \mathrm{g} / \mathrm{mL}$, is in the range of weak active compounds on the MCF7 cell line. The study of Namvar et al. (2014) also showed that the Ulva fasciata methanolic extract with IC50 value of $104 \mu \mathrm{g} / \mathrm{mL}$ on the MDA-MB-231 cell line (after 24h of incubation) was in the range of weakly active compounds. But its IC50 value after 48 and 72 hours of incubation was lower than $100 \mu \mathrm{g} / \mathrm{mL}$ and assigned as moderately active products, unlike the present study. This different cytotoxic effect is probably due to different extraction methods, as the hydro-methanolic extract of the seaweeds was prepared in the present study unlike the pure methanolic extracts of the Namvar et al. (2014) study. Arsianti et al. (2016) was also showed that the hexan fraction of Ulva lactuca has the highest cytotoxic effects. So it is appeared that the cytotoxic effects of the Ulva fasciata and Ulva lactuca depends on the non-polar ingredients.

Breast cancer is a heterogeneous tumor with a wide range of clinical behavior. Patients with the tumor that 
lack the estrogen receptor, progesterone receptor and human epidermal growth factor receptor 2 is called triple negative tumor. These patients are highly resistant to chemotherapy and their disease does not have a good prognosis (Moses et al., 2016). Ulva fasciata and Ulva lactuca seaweeds probably are an appropriate option for the future studies on the triple negative tumors, because of stronger effects of the extracts on the MDA-MB-231 compared to the MCF-7 cell line. Also, it is appeared that their cytotoxic effects is independent of the ER receptor (Banerjee et al., 2017; Erfani et al., 2015). In the study of Erfani et al. (2015) was also showed that the cytotoxic effect of cladophoropsis spp and Gracilaria foliifera seaweeds ethanolic extract was independent of ER receptor. The previous studies have reported a relatively weak cytotoxic effect for the total extract of Ulva fasciata and Ulva lactuca seaweed. So it is recommended that researchers should far from the holistic view of traditional medicine in the future studies and focus on the fractionation and extracting of the bioactive compounds of the Ulva fasciata and Ulva lactuca such as sulfated polysaccharide (Suresh et al., 2012). In addition, it is recommended that the cytotoxic effects of the extracted bioactive was also evaluated on non-tumor cells for monitoring their side effects.

\section{Conclusion}

The Ulva fasciata extract has more cytotoxic effect than Ulva lactuca, which is probably due to the higher phenolic and flavonoid content and its antioxidant activity. The crude hydro-methanolic extracts of Ulva fasciata and Ulva lactuca are assigned as weakly active compounds on the breast cancer cell lines. However, they indicated an estrogen receptor independent manner of cellular growth inhibition that effective in treatment of triple negative tumors. Therefore, the crude extract of the seaweeds (especially Ulva fasciata) was an appropriate drug candidate for fractionation and bioactive extraction.

\section{Acknowledgment}

This work was supported by the Project fund (96119) from the Research deputy of Fasa University of Medical Sciences, Fasa, Iran. The researchers thankful Mrs Bordbar and Dadvari for kindly helping.

\section{Conflict of interest}

The authors declare that they have no known competing financial interests or personal relationships that could have appeared to influence the work reported in this paper.

\section{References}

Arem H, Loftfield E. Cancer epidemiology: a survey of modifiable risk factors for prevention and survivorship. Am J Lifestyle Med 2018; 12: 200-10. https://doi. org/10.1177/1559827617700600

Arsianti A, Wibisono LK, Azizah NN, Putrianingsih R, Murniasih T, Rasyid A, et al. Phytochemical composition and anticancer activity of seaweeds Ulva lactuca and Eucheuma cottonii against breast MCF-7 and colon HCT-116 cells. Asian J Pharm Clin Res 2016; 115-9. https://doi. org/10.22159/ajpcr.2016.v9i6.13798

Atjanasuppat K, Wongkham W, Meepowpan P, Kittakoop P, Sobhon P, Bartlett A, et al. In vitro screening for anthelmintic and antitumour activity of ethnomedicinal plants from Thailand. J Ethnopharmacol 2009; 123: 475-82. https://doi. org/10.1016/j.jep.2009.03.010

Baharum Z, Akim AM, Taufiq-Yap YH, Hamid RA, Kasran $\mathrm{R}$. In vitro antioxidant and antiproliferative activities of methanolic plant part extracts of Theobroma cacao. Molecules 2014; 19: 18317-31. https://doi.org/10.3390/molecules 191118317

Banerjee PP, Bandyopadhyay A, Harsha SN, Policegoudra RS, Bhattacharya S, Karak N, et al. Mentha arvensis (Linn.)-mediated green silver nanoparticles trigger caspase 9-dependent cell death in MCF-7 and MDA-MB-231 cells. Breast Cancer 2017; 9: 265-78. https://doi.org/10.2147/ BCTT.S130952

Chen Z, Bertin R, Froldi G. EC50 estimation of antioxidant activity in DPPH assay using several statistical programs. Food Chem 2013; 138: 414-20. https://doi.org/10.1016/j. foodchem.2012.11.001

El Gamal AA. Biological importance of marine algae. Saudi Pharm J 2010; 18: 1-25. https://doi.org/10.1016/j. jsps.2009.12.001

Erfani N, Nazemosadat Z, Moein M. Cytotoxic activity of ten algae from the Persian Gulf and Oman Sea on human breast cancer cell lines; MDA-MB-231, MCF-7, and T-47D. Pharmacogn Res 2015; 7: 133. https://doi.org/10.4103/09748490.150539

Galavi HR, Saravani R, Shahraki A, Ashtiani M. Anti-proliferative and apoptosis inducing potential of hydroalcoholic 
Achillea wilhelmsii C. Koch extract on human breast adenocarcinoma cell lines MCF-7 and MDA-Mb-468. Pak J Pharm Sci 2016; 29.

Gallego MG, Gordon MH, Segovia FJ, Skowyra M, Almajano MP. Antioxidant properties of three aromatic herbs (rosemary, thyme and lavender) in oil-in-water emulsions. J Ame Oil Chem Soc 2013; 90: 1559-68. https://doi.org/10.1007/ s11746-013-2303-3

Guedes ÉA, da Silva TG, Aguiar JS, de Barros LD, Pinotti LM, Sant'Ana AE. Cytotoxic activity of marine algae against cancerous cells. Rev Bras Farmacogn 2013; 23: 668-73. https://doi.org/10.1590/S0102-695X2013005000060

Hoseini S, Rashidi L, Homapour M. Investigation of polyphenolic compounds and antioxidant properties of black peel pomegranate juice cultivar (Punica granatum) in Saveh. Iran J Nutr Sci Food Technol 2019; 14: 99-108.

Hoseinzadeh F, Shirazinejad A. Study of antioxidant and antimicrobial properties of grape seed extract and evaluation of its sensory characteristics in sponge cake. Food Sci Technol 2019; 15: 165-78.

Langeswaran K, Santhosh Kumar S, Gavaskar S. Antioxidant, anti-microbial and anti-cancer effectiveness of marine macro alga Ulva fasciata Delile. Biomed Res 2019; 30. https:// doi.org/10.35841/biomedicalresearch.30-19-238

Lee JC, Hou MF, Huang HW, Chang FR, Yeh CC, Tang JY, et al. Marine algal natural products with anti-oxidative, anti-inflammatory, and anti-cancer properties. Cancer Cell Int 2013; 13: 1-7. https://doi.org/10.1186/1475-2867-1355

Liu L, Heinrich M, Myers S, Dworjanyn SA. Towards a better understanding of medicinal uses of the brown seaweed Sargassum in Traditional Chinese Medicine: a phytochemical and pharmacological review. J Ethnopharmacol 2012; 142: 591-619. https://doi.org/10.1016/j.jep.2012.05.046

Mashjoor S, Yousefzadi M, Esmaeili MA, Rafiee R. Cytotoxicity and antimicrobial activity of marine macro algae (Dictyotaceae and Ulvaceae) from the Persian Gulf. Cytotechnology 2016; 68: 1717-26. https://doi.org/10.1007/ s10616-015-9921-6

Meshkibaf MH, Abdollahi A, Ramandi MF, Sadati SA, Moravvej A, Hatami S. Antibacterial effects of hydro-alcoholic extracts of Ziziphora tenuior, Teucrium polium, Barberis corcorde and Stachys inflate. Koomesh 2010;11: 240-5. http://koomeshjournal.semums.ac.ir/article-1-792en.html

Mohebbi GH, Nabipour I, Vazirizadeh A. The Sea, the future pharmacy. Iran South Med J 2014; 17: 748-88.
Mosaddegh M, Gharanjik BM, Naghibi F, Esmaeili S, Pirani A, Eslami Tehrani B, et al. A survey of cytotoxic effects of some marine algae in the Chabahar coast of Oman Sea. Res J Pharmacogn 2014; 1: 27-31.

Moses SL, Edwards VM, Brantley E. Cytotoxicity in MCF7 and MDA-MB-231 breast cancer cells, without harming MCF-10A healthy cells. J Nanomed Nanotechnol 2016; 7: 369.

Moulazadeh A, kouhpayeh S.A, Ranjbar R, Dakhili Ardestani A, Hekmat M, Azarnia S, Najafipour S. Antioxidant activity, phenolic and flavonoid content of Lawsonia inermis and Haplophyllum vermiculare. Physiology and Pharmacology 2021; 25: 261-269. http://dx.doi.org/10.52547/phypha.25.3.2

Moulazadeh A, Ranjbar R, Dakhili Ardestani A, Keshavarzi A, Karimzadeh F, Rahnavard M, et al. Evaluation of Phenolic Content, Antioxidant Activity and Cytotoxic Effects of Ulva lactuca and Hypnea musiformis Marine Algae on MDA-MB-468 Cell Line. Journal of Advanced Biomedical Sciences 2021; 11: 3921-8. http://jabs.fums.ac.ir/article-12506-en.html

Moulazadeh A, Kouhpayeh SA. Suitable Concentration of Anti-Inflammatory Herbal Extracts in Cell Culture. Journal of Advanced Biomedical Sciences 2020; 10: 2396-99. http://journal.fums.ac.ir/article-1-2451-en.html

Namvar F, Baharara J, Mahdi AA. Antioxidant and anticancer activities of selected persian gulf algae. Indian J Clin Biochem 2014; 29: 13-20. https://doi.org/10.1007/s12291-0130313-4

Nordin ML, Kadir AA, Zakaria ZA, Abdullah R, Abdullah $\mathrm{MN}$. In vitro investigation of cytotoxic and antioxidative activities of Ardisia crispa against breast cancer cell lines, MCF-7 and MDA-MB-231. BMC Complement Altern Med 2018; 18: 1-10. https://doi.org/10.1186/s12906-0182153-5

Siegel RL, Miller KD, Jemal A. Cancer statistics, 2019. CA Cancer J Clin 2019; 69: 7-34. https://doi.org/10.3322/ caac. 21551

Suresh V, Anbazhagan C, Palani P, Rengasamy R. Protective effect of Ulvan from Ulva lactuca against experimentally induced fibrosarcoma in wistar rats. Int J Curr Sci 2012; 4: 50-6.

Valverde Malaver CL, Colmenares Dulcey AJ, Isaza Martínez JH. Comparison of DPPH free radical scavenging, ferric reducing antioxidant power (FRAP), and total phenolic content of two meriania species (Melastomataceae). Revista de Ciencias 2015; 19: 117-24. https://doi.org/10.25100/ 


\section{rc.v19i2.6271}

Waks AG, Winer EP. Breast cancer treatment: a review. Jama 2019; 321: 288-300. https://doi.org/10.1001/ jama.2018.19323

Wang B, Huang Q, Venkitasamy C, Chai H, Gao H, Cheng N, et al. Changes in phenolic compounds and their antioxidant capacities in jujube (Ziziphus jujuba Miller) during three edible maturity stages. Lwt-Food Sci Technol 2016; 66: 5662. https://doi.org/10.1016/j.lwt.2015.10.005

Zhou Y, Zheng J, Li Y, Xu DP, Li S, Chen YM, et al. Natural polyphenols for prevention and treatment of cancer. Nutrients 2016; 8: 515. https://doi.org/10.3390/nu8080515 